\title{
A CARA DA REBEn
}

Encerramos com este fasciculo o volume 53 da Revista Brasileira de Enfermagem. Foram publicados 64 trabalhos sendo 30 de pesquisa, 4 documentários, 18 ensaios, 6 resumos de dissertação e tese, 6 de revisão, 4 pesquisas de estudantes de graduação, 13 relatos de experiência e 1 de reflexão. Foram avaliados no periodo um total de 91 originais, dos quais $15 \%$ foram recusados. Dos aceitos, 95\% não atendiam às normas de publicação da REBEn e, quando solicitados os ajustes, os autores não responderam ou responderam com atraso. Observação às normas da revista tem sido o maior entrave para publicar. A tradução dos resumos para as linguas espanhola e inglesa permanece como um problema grave, pois é apresentada com erros e isto ocorre com $95 \%$ dos trabalhos analisados. As pesquisas e relatos de experiência respondem por $60 \%$ do material divulgado.

Ainda que a página do estudante seja um espaço privilegiado para divulgar a produção discente, o número de trabalhos que chegam para publicação é pequeno, por isso temos atuado junto às escolas para que estimulem seus alunos a enviar sua produção para análise. Além das pesquisas, as revisões contribuem, sobremaneira, para tornar visivel o estado da arte na área de conhecimento da enfermagem, pois possibilita saber como anda nossa produçăo e que direcionalidade está tendo. No entanto, estes trabalhos não têm despertado o interesse de autores enquanto produçăo.

Embora tenhamos muitos lançamentos de obras de enfermeiras, e a revista disponha de uma seção exclusiva para resenha de livros, poucos autores a utilizam. Parece que as enfermeiras não têm, ainda, incorporado ao seu comportamento a prática de fazer critica à produção de seus pares, talvez porque pesquisadores e consumidores façam parte de uma mesma comunidade e isto cause constrangimento. Este fato dificulta uma maior discussão em torno das publicaçōes, deixando de contribuir para a melhoria das novas produçōes.

Considerando que a REBEn é reconhecida como uma publicação da maior importância para a difusão do conhecimento em Enfermagem no pais, nosso esforço tem sido para que ela mantenha um alto padrão de qualidade, atendendo, assim, as exigências dos seus leitores.

Joel Rolim Mancia

Editor 